\title{
Voices from the marsh: Livelihood concerns of fishers and rice cultivators in the Alaotra wetland
}

Jamieson A. Copsey, Lala Hasina Rajaonarison', Rado Randriamihamina" and Lala Jean Rakotoniainal'"
Correspondence:

Jamieson A. Copsey, Durrell Wildlife Conservation Trust

Les Augrès Manor, Trinity, Jersey, British Channel Islands, JE3 5BP

Phone: +44 (0)1534 860011

E-mail: jamie.copsey@durrell.org

\begin{abstract}
Lake Alaotra is the largest lake on Madagascar and is a centre of rice and freshwater fish production. The lake and its wetland also provide important habitat for endemic wildlife. In 2003 the Alaotra wetland system was designated a Ramsar site and has subsequently been recognized as an official protected area by the Government of Madagascar. While community-based conservation initiatives have led to active involvement of some lakeside communities in the conservation of the aquatic system, wetland destruction continues. The extent to which individuals within these communities perceive the protection of the environment as their priority remains unclear. The current study collected socio-economic data from fishers and rice cultivators living in Anororo, a small town situated on the west coast of Lake Alaotra. Results suggest that livelihood security within these groups is limited. While they hope for better protection of the environment their primary concern is for external investment in their professions. These results highlight the need for solutions to be found to meet current livelihood priorities while efforts continue to conserve natural resources for the future.
\end{abstract}

\section{RÉSUMÉ}

Le lac Alaotra est le plus grand lac de Madagascar et il est un centre de production rizicole et piscicole. Le lac qui a une superficie de 20,000 ha et les zones humides qui l'entourent constituent aussi un habitat important pour des espèces fauniques endémiques. Les initiatives de conservation communautaire impliquant des communautés riveraines dans les actions de protection du système aquatique n'empêchent pas la destruction des zones humides. L'extension des rizières dans les marais de la Nouvelle Aire Protégée (NAP) que des gens de ces communautés pratiquent, montre que ceux-ci perçoivent mal l'importance de la protection de l'environnement, et qu'ils sont loin de pouvoir la considérer en tant que priorité. L'étude actuelle est basée sur des données socio-économiques récoltées auprès de pêcheurs et de cultivateurs d'Anororo, un grand village situé sur la rive ouest du lac Alaotra. Les résultats montrent que la sécurité alimentaire de ces groupes sociaux est limitée car s'ils souhaitent une meilleure protection de I'environnement, leur première inquiétude les incite à investir dans leurs professions. Ces résultats soulignent la nécessité de trouver des solutions pour assurer les moyens de subsistance tout en développant la conservation des ressources naturelles pour le futur. La valorisation de I'utilisation durable des ressources naturelles lacustres et palustres de la NAP sous forme d'activités artisanales génératrices de revenus familiaux améliorera cette subsistance. Elle sera à proposer dans le Plan d'Aménagement et de Gestion Environnementale et Sociale, à élaborer et à adopter prochainement au niveau de chacune des seize communes périphériques du lac dont celle d'Anororo.

KEYWORDS: Lake Alaotra, wetland, Madagascar, livelihood, fisher, rice cultivator.

MOTS CLEF : lac Alaotra, zone humide, Madagascar, subsistance, pêcheur, riziculteur.

\section{INTRODUCTION}

Lake Alaotra covers an area of 20,000 ha in the central highlands of Madagascar (E48 $26^{\prime}, \mathrm{S} 17^{\circ} 31^{\prime}$ ) (Andrianandrasana et al. 2005) (Figure 1). Over 550,000 people live along its shores (Plan Régional de Développement 2003), most of whom practice fishing or rice cultivation as their primary livelihood (BlancPamard 1987, Ranarijaona 2007).

Until recently the Lake Alaotra wetland has been viewed as the 'rice bowl' of Madagascar producing the largest and highest quality harvests on the island (Bakoariniaina et al. 2006). However, due to erosion from the surrounding hills siltation of the rice fields has resulted in a $40 \%$ decline in crop productivity in recent years (Wright and Rakotoarisoa 2003, Bakoariniaina et al. 2006). Similarly, while the lake is an important source of freshwater fish for the island, catches appear to have declined from an annual high of 4,000 tons in the 1960s (Pidgeon 1996) to approximately 2,000 tons per annum in 2003 (Razanadrakoto 2004). Sedimentation and wetland conversion to agricultural land has contributed to the reduction of Lake Alaotra to $20 \%$ of its former size (Bakoariniaina et al. 2006).

Lake Alaotra is also recognized as a centre of freshwater biodiversity within Madagascar. The 23,000 ha of wetland bordering the lake supports the Critically Endangered Alaotran gentle lemur (Andrianandrasana et al. 2005) 


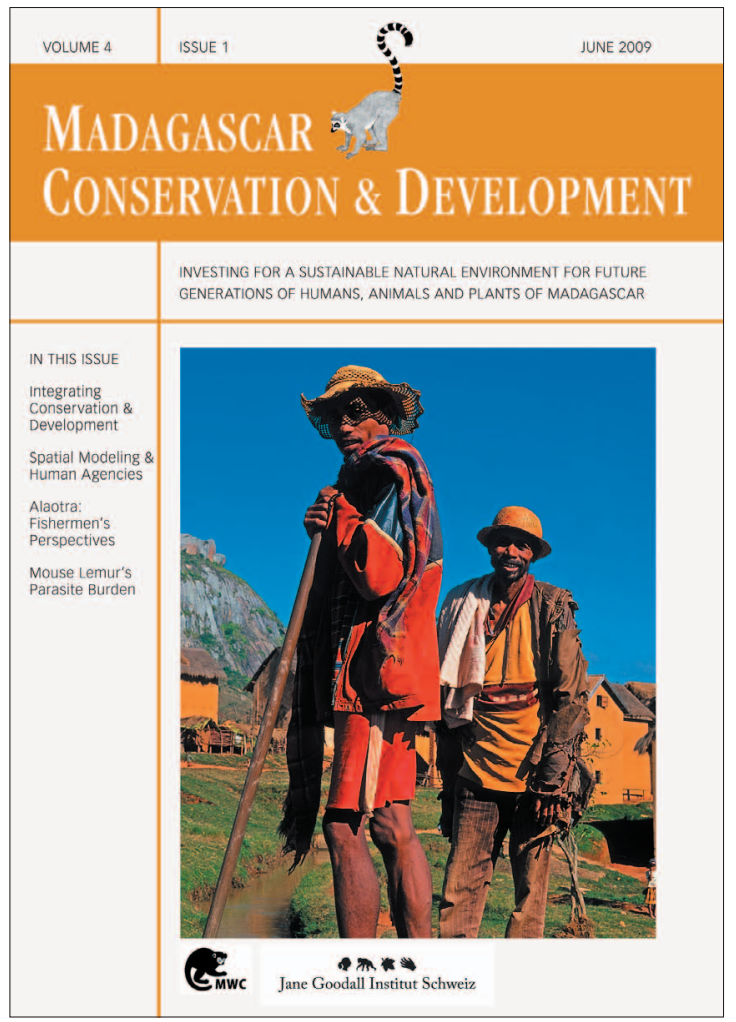

Madagascar Conservation \& Development is the journal of Madagascar Wildlife Conservation (MWC) and the Jane Goodall Institute (JGI Switzerland). It is produced in these institutions' own responsibility.

All the Issues and articles are freely available at http://www.mwc-info.net/en/services/journal.htm

Contact Journal MCD

info@journalmcd.net for general inquiries MCD funding@journalmcd.net for supporting the journal

Journal Madagascar Conservation \& Development Institute and Museum of Anthropology University of Zurich

Winterthurerstrasse 190

$\mathrm{CH}-8057$ Zurich, Switzerland

contact@mwc-info.net for general inquiries

Postfach 2701

CH-8021 Zürich, Switzerland

Logement 11, Cité Andohaniato Antananarivo 101, Madagascar

info@janegoodall.ch for general inquiries JGI

$2 \pi \approx$

Jane Goodall Institut Schweiz
Jane Goodall Institute Schweiz

Postfach 2807

8033 Zürich

Switzerland 


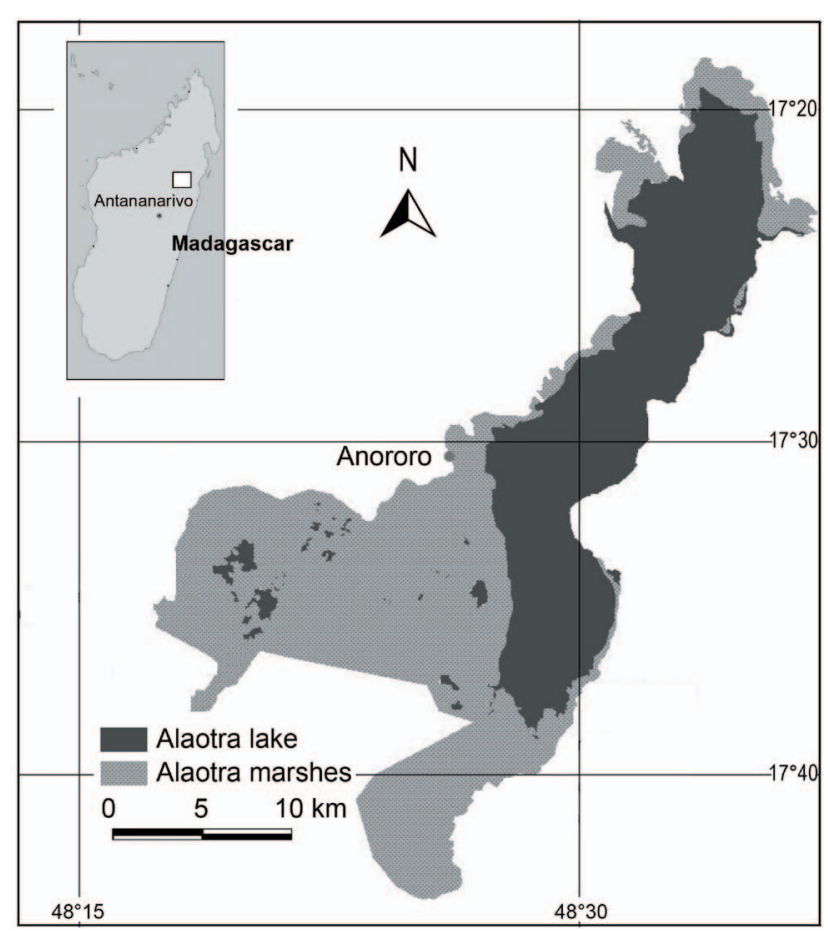

FIGURE 1. Map showing Lake Alaotra and location of the study site, Anororo.

Hapalemur alaotrensis (Groves 2005). At least six endemic species of wildfowl have been observed at the lake as well as six species of endemic fish (Andrianandrasana et al. 2005). In an attempt to conserve the wildlife and the lake as a functioning ecosystem the Durrell Wildlife Conservation Trust launched an education and awareness campaign in lakeside communities in 1996 (Durbin 1999). In 2003 Lake Alaotra was designated a Ramsar site to provide a framework for protecting the remaining wetland (Ramsar 2007). More recently, the Government of Madagascar has classified the lake as a protected area in 2007 (Arrêté N³81-2007/ MINENVEF/MAEP).

Since these initiatives were launched tenure rights to over $35 \%$ of the existing marsh has been transferred from government to local community institutions to manage (Andrianandrasana et al. 2005). Local traditional laws (dina) have been established to ban wetland burning and to regulate fishing activities and wetland use (Andrianandrasana et al. 2005). A two-month closed fishing season has been strictly enforced since 2002 to try to conserve fish stocks (Andrianandrasana et al. 2005).

Despite these efforts the wetland vegetation which surrounds the lake remains under threat through burning of the vegetation during the dry season (Ranarijaona 2007). In 2004, the area of wetland was reduced to almost $47 \%(10,816 \mathrm{ha})$ through burning during the dry season (Table 1). This vegetation provides important nursery grounds for fish, habitat for Hapalemur alaotrensis, and creates an important barrier to siltation and pollution (Andrianandrasana et al. 2005). Multiple reasons have been suggested to explain why people burn the marsh, including a desire for more agricultural land for rice cultivation (Ralainasolo et al. 2006); to aid in poaching H. alaotrensis (Mutschler et al. 2001); to provide space to set fishing nets within the vegetation (Andrianandrasana et al. 2005); and as a form of political protest (Razanadrakoto 2005). The most recent evidence suggests that people are burning the wetland to access the introduced Asian snakehead (Channa maculata), a fish that buries itself in the mud under the vegetation during the dry season (Ranarijaona 2007, copsey et al. In press).

Whether or not wetland burning is motivated by the need to overcome immediate resource limitations (e.g. fish for food) is currently unknown. Fundamentally, little information exists on what local livelihood concerns are and how these correlate with externally-influenced biodiversity conservation goals. The current case study was conducted to begin to address this gap, gathering information directly from lakeside people on the socio-economic realities of life and documenting their main concerns for the future. The data will inform ongoing efforts to conserve Lake Alaotra and its surrounding wetlands and help to balance this goal with a commitment to address immediate livelihood concerns.

\section{METHODS}

The study was conducted over an eight-week period, from May to July 2007. It was based in the fokontany (smallest administrative unit in Madagascar) of Anororo, on the west coast of Lake Alaotra. According to a census published in 2004 (Plan Communal de Développement), Anororo has a population of approximately 8,000 people. Based on the traditional division of the Alaotra marshes, Anororo also possesses 9,850 ha $(42.8 \%)$ of the remaining 23,000 ha of marsh within its boundaries (Andrianandrasana et al. 2005).

Data collection began after an initial 10-day period in the village, providing an opportunity for the leadauthor and townspeople to become familiar with one another. Data were collected using two methods: Semi-structured interviews and questionnaires. Purposive sampling (Bernard 2006) was used to identify individuals for the semi-structured interviews. Interviews were conducted in Malagasy, the second author translating between Malagasy and French for the lead author. In total 27 semi-structured interviews were conducted. The majority of these $(n=23)$ were with fishers; fishers who also grow some rice (fishing-cultivators); or rice cultivators. The remaining four semi-structured interviews were conducted with a butcher, shopkeeper, female fish collector and a female artisan from Anororo. In addition, 10 interviews were conducted with wholesale rice buyers in Anororo to ask them about prices they offer to farmers throughout the year for their rice harvests.

A questionnaire was then designed to test whether the views expressed during interviews reflected those of the townspeople in general and also to obtain more quantitative information on rice production, fish catches and the amount of each that are sold. Questionnaires were written in French, translated into Malagasy and then back-translated to French to check for any misunderstandings caused by language. Questionnaires were administered by the second and third authors, literate respondents being permitted to read the questions themselves. Spatially and temporally structured sampling identified respondents for the questionnaire. One-hour sampling time

TABLE 1. Estimated area of marsh burnt 2000-2004.

Data acquired by estimating area of marsh burnt during previous year's dry season. ${ }^{a}$ Data from Andrianandrasana et al 2005; ${ }^{b}$ Data from Durbin 2006.

\begin{tabular}{|l|l|l|l|l|l|}
\hline Year & $2000^{\mathrm{a}}$ & $2001^{\mathrm{a}}$ & $2002^{\mathrm{a}}$ & $2003^{\mathrm{a}}$ & $2^{2004^{\mathrm{b}}}$ \\
\hline $\begin{array}{l}\text { Marsh area burnt } \\
\text { (ha) }\end{array}$ & 7,300 & 4,430 & 392 & $\begin{array}{l}2,500- \\
2,600\end{array}$ & 10,816 \\
\hline $\begin{array}{l}\text { \% total marsh area } \\
(23,000 \text { h) }\end{array}$ & 31.7 & 19.3 & 1.7 & $>10$ & 47 \\
\hline
\end{tabular}


frames were randomly selected each day, and during these periods all rice cultivators who entered the town from the single track leading from the rice fields into the town were interviewed. For fishers we randomly selected one-hour sampling time frames and locations, as fishers could land their catches at six main locations around the town. In total, 122 questionnaires were conducted face-to-face with 122 male adult fishers, rice cultivators and fishing-cultivators; approximating $5 \%$ of the adult male population in Anororo (Plan Communal de Développement 2004).

\section{RESULTS}

CURRENT LIVELIHOOD CONCERNS. Variability in fish catches

and prices: Mean maximum daily fish catch was $11.4 \mathrm{~kg} \pm 1.9(n=82)$ compared to $3.6 \mathrm{~kg} \pm 0.9(n=82)$ for the mean minimum caught by fishers in Anororo over the seven days prior to completing the questionnaire. According to fishers interviewed a range of factors contribute to this variation. They identified seasonal changes in water temperature and water levels as factors which influenced fish catches, and also short-term variations in the position of the moon, presence or absence of cloud cover and rainfall. They also recognised the type of fishing method employed to influence fish catches. A total of $76 \%$ of questionnaire respondents possessed either fish traps (vovo) or fishing nets (harato). One fisher interviewed stated that particular environmental conditions can influence the effectiveness of the fishing technique employed. According to him when the sky was clear and the moon bright at night the fish would not enter the traps.

Fishers also reported differences in the price they can obtain for the same quantity of fish. According to one fisher interviewed the price difference is partly determined by the species of fish caught. The introduced Common carp (Cyprinus carpio) is the most expensive species (US\$1.5/ kg) and species such as tilapia (Cichlidae) and Asian snakehead (Channa maculata) are the least expensive (US\$1.1/ kg). According to another fisher interviewed there is also a difference in the price offered by the different collectors. The large-scale traders who send their refrigerated lorries from the main towns (e.g. Antananarivo) state the price they will offer to their local collectors at the start of the year. According to this fisher in 2007 these prices varied from US $\$ 0.5 / \mathrm{kg}$ (October-November) to a maximum of US\$1.1/ kg (May-July). In contrast the local traders who transport the fish by bicycle offer a price that is determined by the freshness of the fish. From 0400-0700h they offer US\$1.3/ kg; after 0700h they offer US\$1.2/ kg.

This interviewee was questioned further to ask why he thought other fishers do not use the fish collectors who transport their fish by bicycle, as they would appear to offer the highest price throughout the year. He explained that the large-scale collectors give money (equivalent to US\$ 60) to particular local fishers who then distribute this money to other fishers facing economic hardship. In return recipients of this financial support are expected to sell their fish to the large-scale traders in the future.

Impact of closed fishing season: While there was general support for the goal of the two-month no-fishing period (Durbin et al. 2003), interviewees expressed concern over its immediate impact on their lives. One fisher said that while he recognized the value of the closed season in terms of recovering fish stocks over the longer term, in the meantime he had to borrow money from others in the village in order to feed his family during the closed season. Another fisher stated that he was, "...obliged to go fishing [during the closed season] but without the authorities knowing". A third stated that, "...during the closed fishing season there are people who don't respect the law because they have to eat".

One young couple was discouraged from entering fishing as their sole profession "because during the closed season you cannot earn anything. So it is necessary to be a rice cultivator and a fisher at the same time". The wife of one fisher interviewed added that if the goal of external organizations (e.g. conservation organizations, government institutions) is to develop a sustainable fishing industry they need to help the fishers develop alternative livelihood options during the closed season.

Desire to shift from fishing to rice cultivation: The mean annual income for fishers who responded to the questionnaire was $4,977,818 \pm 997,837$ Ariary ( $n=88)$ (US\$ $2,595 \pm 520$ ) compared to approximately $2,361,904$ Ariary $\pm 1,055,030$ ( $n=73$ ) (US\$ 1,231 \pm 550 ) for rice cultivators in 2007. However, of those fishers who expressed an opinion about future career moves during the interviews $(n=7)$ the majority $(n=4)$ wanted to leave fishing to become rice cultivators. One interviewee stated that while fishing had the potential to generate more income than rice cultivation, income from rice cultivation was more reliable.

The ability of either fishers or rice cultivators to purchase new land now appears to be limited. Landowners do not tend to sell their land once they have acquired it, thereby reducing availability for purchase. Of the 59 land owners questioned, who had owned land for at least the preceding three years (2005-2007), only 11 (18\%) of them had either bought additional land or sold some of their existing land since its original acquisition. Of these 11 landowners only one sold land since he first acquired it in 2005.

VARIABILITY IN RICE HARVESTS AND PRICES. Rice cultivators

who had maintained the same area of land from 2004 onwards $(n=54)$ have experienced large fluctuations in their annual rice harvests (Figure 2). The minimum in 2005 coincided with a reported flood that destroyed harvests and forced villagers out of Anororo. There is a concern that the land developed for rice cultivation around Anororo is declining in productivity. One cultivator explained that earlier on in his career as a rice cultivator the fields were fertile and required little in the way of additional fertilizer to produce healthy crops.

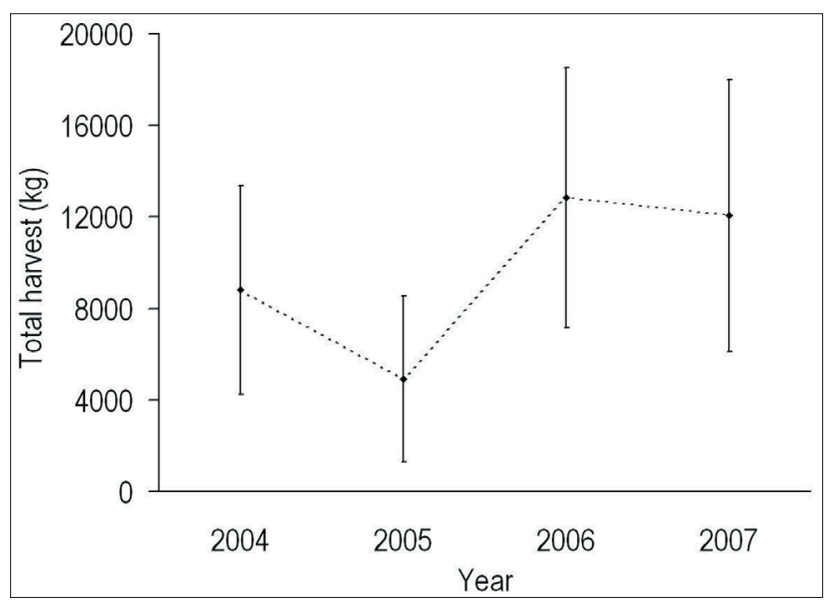

FIGURE 2. Change in reported annual rice harvests (land area staying constant), 2004-2007 ( $n=54)$. Error bars refer to $99 \%$ confidence limits. 
However, now he felt that artificial fertilizers were required to produce a healthy rice harvest. According to him the cost of purchasing these fertilizers was prohibitive in comparison to the income achieved from rice sales. He quoted a cost of 600 Ariary $/ \mathrm{kg}$ [US $\$ 0.35 / \mathrm{kg}$ ] for the fertilizer, while rice could be sold for between 300-400 Ariary/kg [US\$ 0.18-0.2/ kg]. He implied that this was particularly an issue for small-scale rice cultivators who could not buy fertilizers in bulk or hold onto the rice harvests until higher rice prices could be achieved.

Rice cultivators highlighted the increase in sedimentation in the rice fields due to poor irrigation as a current concern, one cultivator stating that "...there is a problem with the irrigation and also the sediment that collects in the rice fields that impoverishes the soil". Human population increase was identified as a causative factor, another cultivator saying that, "...it's because there are lots of people - many people to feed in the family so the harvest is insufficient". The tradition of dividing up land between siblings may be contributing to this pressure. In one example from Anororo an interviewee explained how his parents had owned 27 hectares of land; as a consequence of divisions between siblings this interviewee's children will inherit one hectare each.

The impact of flooding on rice harvests during the rainy season is of particular relevance to the low-lying traditionally managed fields lying outside the irrigated zone. One cultivator stated that, "...a part of [my] rice fields are low-lying and they don't produce [anything]- they are flooded all the time". However, there is now a concern that the more elevated, irrigated rice fields are under threat due to a lack of maintenance of the irrigation channels. According to one couple interviewed they intend, "... starting a second activity, producing textiles, because the production of rice is insufficient as a result of the flooding during the rainy season...the drainage channels and irrigation canals are not dredged ...".

As with fishers, rice cultivators also have to contend with variations in the price for any rice sales made to local rice traders during the year. The mean price offered by ten local rice traders interviewed in Anororo varied from a low of 320 Ariary $/ \mathrm{kg}$ [US $\$ 0.17 / \mathrm{kg}$ ] during the rice harvest in June 2006 to a maximum of 660 Ariary / kg [US\$ $0.34 / \mathrm{kg}$ ] in December 2006.

One rice cultivator expressed a view that the large-scale rice collectors from outside of Anororo are suppressing rice prices. According to him the regional micro-finance facility expects farmers to repay loans by the end of August. Again according to this one interviewee the large-scale rice collectors from the major cities know of this deadline and so keep the price they are willing to pay for rice from the cultivators low until after this date. He stated that by doing so rice collectors were able to force rice cultivators in the town to sell their rice to them at a low price.

HOPE FOR THE FUTURE. Respondents to the question-

naire were asked to give their hopes and aspirations for the future. Hopes were defined as the changes they would like to see happening in an ideal world that would be of greatest importance to them as individual villagers. While many respondents to this question $(n=43)$ expressed a desire for the wetland to be protected, the majority $(n=57)$ were concerned with obtaining external investment in fishing and rice cultivation (Figure 3). A desire for fish and rice prices to be better regulated was also commonly cited.

\section{DISCUSSION}

The primary concern of fishers and rice cultivators living in Anororo is how to contend with variability in their respective harvests and the financial returns they can expect from them. While they voice a hope for better environmental protection in the future, their principle desire is for economic support for their livelihoods. Linked to this is a hope for better regulation of both fish and rice prices so they can better predict the incomes they will receive.

Variability in fish catches is a fact of life for fishers globally (Acheson 1981, McGoodwin 1990: 7-20). It has been suggested that around Alaotra fish catches are highest when the rains come and the water level of the lake rises between December and February (Blanc-Pamard 1987). According to fishers interviewed in the current study fish catches can vary on a daily basis depending on the location; the equipment used; the position of the moon; the temperature; as well as water height.

Regardless of how much fish is caught, small-scale fishers around the world also have to contend with variability in the income they can receive (McGoodwin 1990: 7-20). In Anororo fish prices vary depending on the species caught, who the fish is sold to and when the fish is sold. Although higher prices can be obtained from the small-scale 'bicycle' fish traders the large-scale collectors from Antananarivo and elsewhere have the financial means to secure fisher's loyalty. This sort of relationship between fisher and fish trader is not uncommon in small-scale fishing societies (Acheson 1981). Due to the unpredictability of fishing as a livelihood fishers may find it difficult to access capital through the normal banking system. Traders can take advantage of this by providing fishers with a necessary financial cushion during hard times in return for long-term access to their fish catches at competitive rates.

The establishment of a two-month closed fishing season in Alaotra would appear to be compromising fisher's ability to make a living, at least over the short-term. Diversity of livelihood can provide resilience to the external impacts of catastrophes (such as fish population crashes) and regulations, such as those imposed in Alaotra. Whether or not any reduction in income from fishing is being compensated for by other work is an area requiring further research. Livelihood diversification is a common feature of the rural economy across Africa (Barrett et al. 2001). In particular it would be important to investigate the role of women's earnings on household income. For example women in lakeside communities around Alaotra are involved in the production and sale of baskets, mats and hats woven from

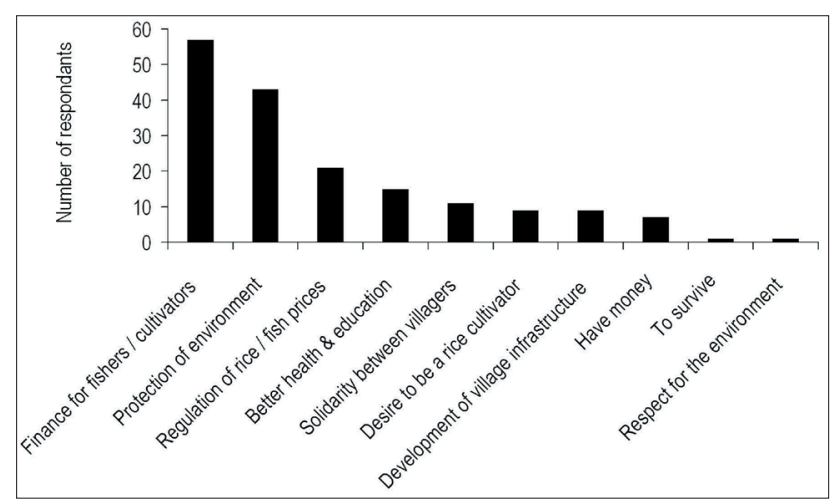

FIGURE 3. Hopes for the future expressed by questionnaire respondents $(n=116)$. 
reeds growing in the wetland (Jarosz 1994). Local fish traders and consumers may also be adversely affected by the closure; as such controls can cause disruptions to markets as supply is discontinued (McGoodwin 1990: 7-20).

Fishers in Anororo reported mean annual earnings of US $\$ 2,780$ in 2007, which is more than double that reported for rice cultivators (US\$1,335) and over three times the mean GDP per capita for Madagascar of US\$ 856 in 2006 (UNDP 2006). A study conducted by Andrianandrasana (2005) estimated mean salaries around Lake Alaotra to be between US $\$ 1,000-1,500$ per annum, highlighting the relatively high incomes that can be gained from fishing in Anororo at present. Despite this fishers report a desire to move into rice cultivation. This shift may in part be due to a desire to achieve a degree of food security (Smith et al. 2005). In a study conducted by Barrett (1994) up to $85 \%$ of the rice harvested in Madagascar was retained for subsistence. Therefore, although fishers on average may be able to earn higher annual incomes than rice cultivators they are unable to secure a supply of rice for family consumption, unlike rice cultivators.

Even if fishers have the capital to purchase land there appears to be limited opportunity to do so. Land scarcity is a major problem facing rice farmers in this area (Randrianarisoa and Minten 2001). Immigration pressure may have played a role in this increased competition for the same area of land. Since the establishment of irrigated rice fields in the 1960s there has been unprecedented immigration into the Alaotra region (Garin et al. 1994). The tradition of dividing land between siblings has also had an impact. A study conducted on land ownership around Lake Alaotra concluded that over $40 \%$ had been inherited from other family members (Jacoby and Minten 2007). Elsewhere in Madagascar this form of land division between siblings is putting additional pressure onto the land to produce (Kistler and Spack 2003). Land can be rented in return for an amount of money or a proportion of the harvest (Blanc-Pamard 1987). However, rice cultivation around Anororo does not come without its own risks and vulnerabilities.

Soil degradation is a significant problem for rice cultivators in this area (Randrianarisoa and Minten 2001). Cultivators interviewed in the present study perceived a reduction in soil fertility and the impact this has on small-scale farmers who may be unable to purchase the chemical fertilisers necessary to maintain soil fertility. Sedimentation and flooding of the rice fields is further reducing rice harvests, according to villagers interviewed. Sedimentation in the lake has been accentuated due to deforestation in the hills surrounding the wetland (Andrianandrasana et al. 2005), which in turn is reducing the productivity of the land (Bakoariniaina et al. 2006). Serious flooding of standing rice fields in the eastern Alaotra region was reported for the start of March 2005 (FAO 2005). Increased siltation of the drainage channels is increasing the susceptibility of the rice-growing land to flooding (McHugh et al. 2003). Mean rice harvests in 2005 reported by rice cultivators during the present study were less than half that given for 2006 and 2007, suggesting a potentially devastating impact on household security for those farmers normally able to meet subsistence needs only.

Even when farmers are able to produce a surplus of rice for sale they may well be forced to sell any excess immediately after the harvest in order to repay personal debts incurred leading up to the harvest. Interviewees in the current study mentioned the need to repay debts incurred immediately following the harvest. one interviewee claimed that the large-scale rice collectors were forcing indebted farmers to sell their rice at a low price as the farmers were obliged to repay their micro-finance loans within a fixed period. Local elites, backed by State officials have reportedly continued to dictate rice prices around Alaotra, thereby preventing free-market forces to operate (Barrett 1994). By selling immediately after the harvest these small-scale producers are unable to take advantage of price increases that occur later in the year as availability of rice locally declines.

For rice consumers these price changes will also have an impact. The majority of rice farmers in Madagascar are in fact net consumers of rice (Barrett 1994). For those farmers in Anororo unable to meet their subsistence needs and those individuals who grow no rice at all, these price changes are likely to put extra strain on an already fluctuating income-base.

Not surprisingly, the main hope for the future expressed by fishers and rice cultivators alike was for external investment into their professions. The results of a development workshop run by the regional government in Anororo to determine the main concerns of people within the village showed that their principal desire was for improvements in production (Plan Communal de Développement 2004). In this workshop preservation of the natural resource base was ranked eighth, bottom in terms of their priorities for change. While it is unknown to what extent and in what format people within the village contributed to this workshop the low concern placed on the environment in comparison to improving production suggests that the priority for local people is for immediate livelihood improvements and not long-term environmental protection.

\section{CONCLUSION}

There is little doubt that the loss of Lake Alaotra and its surrounding wetland area will not only threaten local biodiversity but will further reduce livelihood security for lakeside communities. However, conservation measures designed to achieve long-term goals must reflect the immediate concerns of local communities. Further research should be conducted in other lakeside communities to determine the extent to which they express the same views and concerns as those expressed by people in Anororo. Additional studies are required to establish the extent to which alternative livelihoods (e.g. producing reedbased textiles for sale) do currently or could in the future provide resilience for fishers and rice cultivators during hard times. In the case of Anororo, one answer may be for non-government (e.g. conservation charities) or government organizations to provide financial resources to support the development of fishing and rice cultivation in order to secure livelihoods. Ultimately, if future conservation-oriented goals are to be achieved they must in the meantime provide additional resilience for the lives and livelihoods of the people of the marsh.

\section{ACKNOWLEDGEMENTS}

We thank the Government of Madagascar and the people of Anororo for providing permission to conduct the study, and the Royal Anthropological Institute (Ruggles-Gates Fund for Biological Anthropology), the Parkes Foundation, the British Institute in Eastern Africa, University College London and the States of Jersey for financial support. Katherine Homewood read and commented on early drafts of this manuscript. 


\section{REFERENCES}

Acheson, J. M. 1981. Anthropology of fishing. Annual Review of Anthropology 10: 275-316. (doi:10.1146/annurev.an.10.100181.001423)

Andrianandrasana, H. T. 2005. Four Years of Experience in Participatory Ecological Monitoring: The Case of Lake Alaotra in Madagascar. Unpubl. report, Durrell Wildlife Conservation Trust, Antananarivo, Madagascar.

Andrianandrasana, H. T., Randriamahefasoa, J., Durbin, J., Lewis, R. E. and Ratsimbazafy, J. H. 2005. Participatory ecological monitoring of the Alaotra wetlands in Madagascar. Biodiversity and Conservation 14, 11 2757-2774. (doi:10.1007/s10531-005-8413-y)

Bakoariniaina, L. N., Kusky, T. and Raharimahefa, T. 2006. Disappearing Lake Alaotra: Monitoring catastrophic erosion, waterway silting, and land degradation hazards in Madagascar using Landsat imagery. Journal of African Earth Sciences 44, 2: 241-252. (doi:10.1016/j.jafrearsci.2005.1 0.013)

Barrett, C. B. 1994. Understanding uneven agricultural liberalisation in Madagascar. The Journal of Modern African Studies 32, 3: 449-476. (doi:10.1017/S0022278X00015184)

Barrett, C. B., Reardon, T. and Webb, P. 2001. Nonfarm income diversification and household livelihood strategies in rural Africa: Concepts, dynamics, and policy implications. Food Policy 26, 4: 315-331. (doi:10.1016/ S0306-9192(01)00014-8)

Bernard, H. R. 2005. Research Methods in Anthropology: Qualitative and Quantitative Approaches (4 ${ }^{\text {th }}$ Edition). Altamira Press, Walnut Creek, California.

Blanc-Pamard, C. 1987. Systèmes de production paysans et modèle rizicole intensif : deux systèmes en décalage. L'exemple des riziculteurs de la SOMALAC sur les Hautes Terres centrales de Madagascar. Cahiers ORSTOM des Sciences Humaines 23, 3-4: 507-531.

Copsey, J. A., Jones, J. P. G., Andrianandrasana, H. and Fa, J. E. In press. Burning to fish: Local explanations for wetland burning in Lac Alaotra, Madagascar. Oryx. (doi:10.1017/S003060530900052)

Durbin, J. 1999. Lemurs as flagships for conservation in Madagascar. In: New Directions in Lemur Studies. B. Rakotosamimanana, H. Rasamimanana, J. Ganzhorn and S. M. Goodman (eds.), pp 269-281. Plenum, New York.

Durbin, J., Rakotoniaina, L. J. and Randriamahefasoa, J. 2003. Project Alaotra: Using endangered species as flagships for community-based wetland conservation. In: The Natural History of Madagascar. S. M. Goodman and J. P. Benstead (eds.), pp 1551-1555. The University of Chicago Press, Chicago

Durrell, J. 2006. Rapport Annuel 2006. Durrell Wildlife Conservation Trust Programme Madagascar. Unpubl. report. Durrell Wildlife Conservation Trust Programme, Antananarivo, Madagascar.

FAO. 2005. Global Information and Early Warning System on Food and Agriculture. Food Supply Situation and Crop Prospects in Sub-Saharan Africa No. 1. <ftp://ftp.fao.org/docrep/fao/007/J4758e/J4758e00.pdf> accessed 12 February 2009

Garin, P., Teyssier, A. and Elson, L. N. 1994. More secure landholding and relationship between agriculture and livestock production at lac Alaotra (Madagascar). In: International Symposium: Systems-oriented research in agriculture and rural development. M. Sebillote (ed.), pp 284-285. CIRAD-SAR, Montpellier, France.

Groves, C. 2005. Order Primates. In: Mammal Species of the World: A Taxonomic and Geographic Reference (Third edition), D. E. Wilson and D. M. Reader (eds.), pp 111-184. The Johns Hopkins University Press, Baltimore.

Jacoby, H. G. and Minten, B. 2007. Is land titling in Sub-Saharan Africa cost-effective? Evidence from Madagascar. The World Bank Economic Review 21, 3: 461-485.

Jarosz, L. 1994. Taboo and time-work experience in Madagascar. Geographical Review 84, 4: 439-450.

Kistler, P. and Spack, S. 2003. Comparing agricultural systems in two areas in Madagascar. In: The Natural History of Madagascar. S. M. Goodman and J. P. Benstead (eds.), pp 123-134. The University of Chicago Press, Chicago.

McGoodwin, J. R. 1990. Crisis in the World's Fisheries People, Problems and Policies. Standford University Press, Stanford, California.
McHugh, O. V., Barison, J., Steenhuis, T. S., Fernandes E. C. M. and Uphoff, N. T. 2003. Farmer implementation of alternate wet-dry and non-flooded irrigation practices in the System of Rice Intensification (SRI). In: Water-Wise Rice Production. Proceedings of a Thematic Workshop on Water-Wise Rice Production. B. A. M. Bouman, H. Hengsdijk, B. Hardy, P. S. Bindraban, T. P. Tuong and J. K. Ladha (eds.), pp 8-11. IRRI headquarters in Los Baños, Philippines.

Mutschler, T., Randrianarisoa, A. J. and Feistner, A. T. C. 2001. Population status of the Alaotran gentle lemur Hapalemur griseus alaotrensis. Oryx 35, 2: 152-157 (doi:10.1046/j.1365-3008.2001.00167.x)

Pidgeon M. 1996. Lake Alaotra and Wetlands of Central and Eastern Madagascar Unpubl. report. Missouri Botanical Garden, Antananarivo, Madagascar.

Plan Communal de Développement. 2004. Unpubl. report. Commune Rurale Anororo- FID, Toamasina, Madagascar.

Plan Régional de Développement. 2003. Zone de Développement Rural Intégral de I'Alaotra (Z.D.R.I). Unpubl. report. CORDAL Ambatondrazaka, Madagascar.

Ralainasolo, F. B., Waeber, P. O., Ratsimbazafy, J., Durbin, J. and Lewis, R. 2006. The Alaotra gentle lemur: Population estimation and subsequent implications. Madagascar Conservation \& Development 1, 1: 9-10.

Ramsar. 2007. Signatories and Sites <http://www.ramsar.org> accessed 12 February 2009.

Ranarijaona, H. L. T. 2007. Concept de modèle écologique pour la zone humide Alaotra. Madagascar Conservation \& Development 2, 1: 35-42.

Randrianarisoa, J. C. and Minten, B. 2001. Agricultural Production, Agricultural Land and Rural Poverty in Madagascar. Cornell University <http://www.ilo.cornell.edu/images/wp112.pdf> accessed 11 February 2009.

Razanadrakoto, D. 2004. Rapport Annuel 2003 CIRPRH. Circonscription de la Pêche et des Ressources Halieutiques. Unpubl. report. Ambatondrazaka, Madagascar.

Razanadrakoto, D. 2005. Rapport annuel 2005. SRPRH. Service Régional de la Pêche et des Ressources Halieutiques, Ambatondrazaka, Madagascar.

Smith, L. E. D., Nguyen Khoa, S. and Lorenzen, K. 2005. Livelihood functions of inland fisheries: Policy implications in developing countries. Water Policy 7: 359-383.

UNDP. 2006. Human Development Report 2006 Human Development Indicators Country Fact Sheets Madagascar <http://hdr.undp.org/ hdr2006/statistics/countries/country_fact_sheets/cty_fs_MDG.html> accessed 09 February 2009.

Wright, H. T. and Rakotoarisoa, J.-A. 2003. Human ecology. In: The Natural History of Madagascar. S. M. Goodman and J. P. Benstead (eds.), pp 112-178. The University of Chicago Press, Chicago. 